\title{
INSTAGRAM SEBAGAI RUANG KOMUNIKASI VIRTUAL ANTARA PEMIMPIN DAERAH DENGAN PUBLIK PADA SAAT PANDEMI COVID-19
}

\author{
Lilik Darmawan \\ Magister Ilmu Komunikasi FISIP \\ Universitas Jenderal Soedirman \\ Purwokerto \\ lilikdarmawan.2019@gmail.com
}

\begin{abstract}
Abstrak. Penelitian ini bertujuan untuk mengkaji dan menganalisis komunikasi yang dilakukan Bupati Banyumas Achmad Husein melalui akun @ir_achmadhusein dengan mendeskripsikan komunikasi antara Bupati Banyumas dengan masyarakat di ruang publik virtual. Serta menganalisis isi pesan yang disampaikan oleh Bupati Banyumas dan masyarakat dalam ruang virtual di akun Instagram dalam kurun waktu Maret hingga Juni 2020. Penelitian menggunakan pendekatan kualitatif deskriptif terhadap akun Instagram Bupati Banyumas Achmad Husein@ir_achmadhusein dengan metode virtual etnografi. Dalam penelitian ini, penulis melakukan pengamatan akun Instagram Bupati Banyumas dan interaksiny dengan pengikutnya. Hasil penelitian menunjukkan bahwa Bupati Banyumas menggunakan fitur-fitur yang ada di Instagram untuk memberikan sosialisasi dan informasi terkait Covid-19 kepada masyarakat.
\end{abstract}

Kata Kunci: Etnografi virtual, Kualitatif, Instagram, Ruang Virtual

Abstract. This study aims to examine and analyze the communication made by the Regent of Banyumas Achmad Husein through the account @ir_achmadhusein. By describing communication between the Regent of Banyumas and the community in a virtual public space. As well as analyzing the contents of messages delivered by the Regent of Banyumas and the community in a virtual space on the Instagram account in the period March to June 2020. This study uses a descriptive qualitative approach to the Banyumas Regent Instagram account Achmad Husein @ir_achmadhusein with a virtual ethnographic method. In this study, the authors observed the Banyumas Regent Instagram account and interacted with his followers. The results showed that the Banyumas Regent used the features in Instagram to provide information and information related to Covid-19 to the public. Keywords: Virtual ethnography, qualitative, Instagram, virtual space

\section{Pendahuluan}

Teori ekologi media yang dikemukakan oleh Marshall Mc Luhan memaparkan bagaimana teknologi memengaruhi masyarakat. Dalam teori ekologi media tersebut, menurut West, et al (2010), ada tiga asumsi pembingkai teori tersebut, yakni media menanamkan tindakan dalam masyarakat, memperbaiki persepsi dan mengatur pengalaman, media mengikat dunia bersama.

Dengan adanya perubahan teknologi, maka akan berdampak pada 
perubahan pola komunikasi. Menurut Cangara (2018), kemajuan teknologi yang begitu cepat telah mengubah pola-pola kehidupan manusia di atas bumi. Perubahan yang terjadi hampir terjadi di seluruh sektor seperti penggunaan $e$-book dan $e$ newspaper, email, paperless, serta pemesanan ojek dan taksi dengan berbasis komunikasi internet. Komunikasi berbasis teknologi tersebut akan memperpendek jarak, efisiensi waktu dan mobilitas. Berkat perkembangan teknologi komunikasi khususnya bidang komunikasi massa yang begitu cepat, media massa elektronik makin banyak bentuknya dan kian mengaburkan batas-batas untuk membedakan antara media komunikasi massa dan media komunikasi pribadi. Hal ini disebabkan karena makin canggihnya media komunikasi itu sendiri yang dapat dikombinasikan atau multimedia.

Menurut Susanto (2017), pengguna media sosial secara individual, kelompok maupun institusional, dapat bertindak sebagai pengirim maupun penerima pesan dalam komunikasi di dunia maya. Fleksibilitas pemanfaatan media sosial tidak dibatasi oleh status status sosial, ekonomi dan politik yang ada di masyarakat. Media sosial memiliki kemampuan dalam kecepatan menyampaikan pesan kepada khalayak atau pengguna media sosial lainnya karena dukungan teknologi komunikasi yang mampu menjangkau khalayak lebih luas dan lebih cepat. Keunggulan ini meminggirkan pemberitaan media massa arus utama, yang memerlukan proses panjang dan verifikasi keseimbangan informasi dari sumber pesan yang dipercaya. Stratifikasi politik yang melekat pada pengguna media sosial berkaitan pula dengan perbedaan dalam menyikapi informasi yang diterima namun memiliki kesamaan dalam mendukung jaringan komunikasi politik untuk mencapai tujuan yang telah ditetapkan.

Pada saat sekarang terutama selama masa pandemi Covid-19 yang masih terus berlangsung, menurut Perez (2020), beberapa media sosial seperti Instagram dan Whatsapp mengalami peningkatan penggunaan hingga lebih dari $40 \%$. Penggunaan media sosial seperti Instagram, tidak hanya digunakan oleh pribadi saja, melainkan juga menjadi saluran resmi pemerintah. Menurut Anggreani (2020), seiring berkembangnya zaman yang didukung oleh pesatnya pertumbuhan teknologi, kemudian dipopulerkan pula dengan adanya istilah revolusi industri 4.0, membawa pengaruh yang signifikan bagi media, khususnya ruang publik virtual yang sangat mudah dijangkau oleh setiap individu. Peran ruang publik virtual semakin besar, dimana fungsinya bukan lagi hanya sebatas sumber informasi dan alat berkomunikasi, namun segala bentuk aktivitas publik pun dapat berputar di dalamnya, termasuk untuk proses demokrasi, berpolitik, sampai penyampaian aspirasi oleh masyarakat luas kepada para pemimpin negara. Berbicara mengenai ruang publik virtual, banyak sekali bentuk atau perwujudan dari sarana berkomunikasi yang imajiner ini. Saat ini ruang publik virtual lebih dikenal dengan media sosial, dan bentuk-bentuk dari media sosial ini sangat banyak. Beberapa perwujudan dari ruang publik virtual ini menjadi pendukung pesatnya penyebaran serta akses berbagai informasi, termasuk di dalamnya informasi yang menyangkut segala kebijakan pemerintah. Dewasa ini pemanfaatan media sosial sudah masuk ke dalam ranah pemerintah.

Sementara penelitian Prajarto (2018), menjelaskan bahwa perkembangan teknologi komunikasi telah mengubah lanskap industri hiburan tanah air secara 
signifikan Akun Instagram Lambe Turah sebagai salah satu media infotainment di media sosial menjadi salah satu sumber informasi yang mampu mengakomodasi kebutuhan ini. Akibatnya, banyak netizen yang akhirnya mengakses informasi dari akun Lambe Turah. Catatan menarik terkait relasi antara netizen dan akun Lambe Turah berpusat pada peran netizen yang tidak serta merta ditempatkan hanya sebagai objek penerima informasi. Netizen memiliki peran signi kan baik dalam tataran produksi dan reproduksi konten. Partisipasi aktif netizen dalam memproduksi konten informasi diwujudkan, misalnya melalui praktik citizen journalism terkait industri hiburan yang kemudian disampaikan kepada admin akun Lambe Turah sebagai gate keeper informasi. Selain itu, partisipasi aktif netizen juga ditunjukkan melalui reproduksi informasi melalui tur komentar yang memungkinkan diskusi dan wacana terkait isu yang disampaikan dalam konten unggahan Lambe Turah terus berkembang. Partisipasi aktif netizen dalam mengatur arah aliran diskusi dan wacana yang berkembang pada satu titik menempatkan mereka pada tiga posisi yaitu pemberi, pelengkap, dan penyanggah informasi. Sejatinya, ketiga peran ini kian menguatkan peran aktif netizen dalam akun Lambe Turah. Menariknya, netizen dalam akun LambeTurah juga menciptakan struktur bahasa yang kemudian banyak diadopsi oleh masyarakat yang bahkan mungkin tidak pernah mengaksesnya. Kuatnya peran netizen dalam akun Lambe Turah menegaskan bahwa tulang punggung media infotainment di platform media sosial adalah aktivitas yang dilakukan oleh para netizen itu sendiri. Konsep audiens aktif yang dicerminkan melalui tiga peran yaitu pemberi, pelengkap, dan penyanggah informasi mencerminkan signifikansi netizen sebagai sosok vital dalam proses transmisi informasi di media baru.

Penelitian Duraisamy et al (2020), mengunngkap bahwa media sosial telah mengubah cara orang berkomunikasi di seluruh dunia, secara instan dan tanpa batas. Di era baru media yang saling terhubung, ledakan Covid-19, pandemi yang disebabkan oleh coronavirus, telah dikalahkan oleh informasi yang salah terkait pandemi yang menyebar di antara jutaan orang di seluruh dunia. Informasi palsu dapat mengakibatkan dampak dunia nyata yang luas, melalui platform web dan media sosial, karena dapat dibuat dan disebarkan dengan mudah. Ada ribuan informasi palsu yang beredar di berbagai sosial platform media termasuk Facebook, WhatsApp, Twitter, TikTok, dan lainnya, bahkan setelah Pemerintah telah mengambil sejumlah langkah untuk mempengaruhi hasil wabah dengan cara terbaik.

Pada era pasca-kebenaran, media sosial masih bisa menjadi tempat terbaik untuk menyebarkan informasi jika orang-orang di jejaring sosial mengirimkan berita dari sumber yang dapat dipercaya. Berkenaan dengan pandemi Covid-19, lebih banyak konten yang dibuat pengguna atau diedit oleh pengguna berkontribusi besar terhadap informasi yang salah daripada informasi faktual. Informasi yang salah menyebar jauh lebih cepat daripada yang bisa ditampung atau dikendalikan oleh platform ini. Meskipun beberapa konten menjelaskan situasi aktual, mereka dilawan oleh sejumlah besar informasi palsu atau informasi yang salah, menyesatkan masyarakat umum yang tidak mengetahui situasi aktual.

Mereka harus memastikan bahwa informasi dan data yang benar dari sumber yang dapat dipercaya dibagikan dan disebarkan untuk menciptakan 
kesadaran yang dibutuhkan untuk hasil yang positif. Sebagai warga yang bertanggung jawab secara sosial, masyarakat harus menahan diri dari menyebarkan informasi yang tidak akurat, belajar memverifikasi dan memvalidasi informasi, dan memeriksa kredibilitas informasi yang luas.

Sejak munculnya kasus Covid-19 di Banyumas, Bupati Banyumas Achmad Husein dengan akun Instagram @ir_achmadhusein sebagai representasi pemerintah daerah mulai melakukan sosialiasi pandemi Covid-19 kepada masyarakat Banyumas. Dengan akun Instagram tersebut, Bupati mulai memberikan pernyataan secara resmi mulai 8 Maret lalu. Dengan akun tersebut, hampir setiap hari Bupati memberikan pernyataan dan sosialisasi kepada masyarakat luas. Akun resmi Bupati Banyumas Achmad Husein tersebut telah 95,9 ribu pengikut.

Adapun tujuan dari penelitian ini adalah untuk mengkaji dan menganalisis komunikasi yang dilakukan Bupati Banyumas Achmad Husein melalui akun @ir_achmadhusein dengan mendeskripsikan komunikasi antara Bupati Banyumas dengan masyarakat di ruang publik virtual serta menganalisis isi pesan yang disampaikan oleh Bupati Banyumas dan masyarakat dalam ruang virtual di akun Instagram dalam kurun waktu Maret hingga Juni 2020.

\section{METODE PENELITIAN}

Penelitian ini menggunakan pendekatan kualitatif deskriptif terhadap akun Instagram Bupati Banyumas Achmad Husein@ir_achmadhusein dengan metode virtual etnografi. Dalam penelitian ini, penulis melakukan pengamatan akun Instagram Bupati Banyumas mulai Maret hingga akhir Juni 2020 atau selama empat bulan. Menurut Hine (2000), virtual etnografi dipakai untuk investigasi atas penggunaan internet yang memiliki makna bagi kehidupan sosial masyarakat. Media interaktif dipahami sebagai budaya itu sendiri maupun sebuah artefak budaya. Dengan menggunakan metode etnografi virtual, maka bisa mengumpulkan data yang lebih kaya, sebab bekerja di dunia siber. Serlain itu dapat dilihat interaksi yang termediasi dalam ranah virtual. Lamanya waktu tidak ada batasan yang pasti, tergantung kebutuhan data dan analisis yang dilakukan, bisa tiga bulan, satu tahun, tiga tahun dan seterusnya.

\section{TINJAUAN PUSTAKA}

Warganet memilih media sosial menjadi salah satu aplikasi yang digunakan karena media sosial bisa digunakan untuk pertukaran konten yang dibuat pengguna dan memungkinkan interaksi antarpengguna. Taprial \& Kanwar (2012) menyatakan bahwa orang-orang tertarik untuk berjejaring dan terhubung dengan teman-teman, berbagi konten, mengirim pesan, berkolaborasi satu sama lain secara 
real-time, mengumpulkan berita, informasi, umpan balik atau hanya mengunggah, mengunduh file media di Internet. Media sosial memiliki beberapa sifat yang melekat yang membuatnya jauh lebih kuat daripada media tradisional. Media sosial memiliki ciri yakni aksesibilitas, kecepatan, interaktif, volatilitas, dan jangkauan. Pertama,. aksesibilitas adalah mudah diakses dan membutuhkan biaya minimal. Bahkan, media sosial mudah digunakan dan tidak memerlukan pengetahuan dan keterampilan yang khusus. Kedua kecepatan, di mana sangat gampang untuk secepatnya mengunggah konten di akun masing-masing. Ketiga interaktif, media sosial menawarkan saluran komunikasi dua arah atau ganda. Pengguna dapat berinteraksi satu sama lain seperti mengajukan pertanyaan dan mendiskusikannya. Keempat volatilitas, yaitu konten media sosial dapat diakses untuk waktu yang lama dan karena sifat mediumnya, maka mungkin bisa selamanya. Kelima jangkauan, internet menawarkan jangkauan tidak terbatas ke semua konten yang tersedia. Akses dapat di mana saja dan semua orang dapat menjangkaunya.

Perkembangan media sosial di Indonesia semakin meningkat dari tahun ke tahun. Dalam survei yang dilakukan lembaga We Are Social, Hoorsuite (2020), Instagram merupakan salah satu media sosial terbanyak yang dimanfaatkan oleh warganet. Data dari survei tersebut menyebutkan bahwa 88\% warganet di Indonesia merupakan pengguna YouTube, kemudian aplikasi WhatsApp 84\%, Facebook $82 \%$, Instagram $79 \%$, dan Twitter 56\%. Jumlah pengguna media sosial di Indonesia sebanyak 160 juta atau 58\% dari total jumlah penduduk. Warganet berusia 16-64 tahun. Dari jumlah tersebut, $99 \%$ berselancar melalui telepon seluler.

Farhatiningsih dan Irwansyah (2018), menyebutkan bahwa perkembangan media sosial mengharuskan humas pemerintah untuk menggunakan teknologi komunikasi dengan cara menarik dan bermakna Kehadiran media sosial memudahkan pemerintah dalam melakukan komunikasi dua arah dengan masyarakat. Oleh sebab itu, dengan melakukan dialog dua arah melalui media sosial, pemerintah dapat dengan cepat mengatasi kekhawatiran warga negara dan mengurangi perasaan serta komentar negatif. Instagram sebagai salah satu media sosial untuk membuat suatu argumen persuasif di masyarakat mengenai kebijakan tertentu melalui gambar atau video yang diunggah. Keutamaan gambar dalam Instagram yang juga menggunakan teks dapat mengkomunikasikan suatu pesan bahkan lebih efektif. Hal ini diperlukan oleh pemerintah dalam menyampaikan suatu kebijakan kepada masyarakat. Instagram meningkatkan kehadiran dan identitas online, dan memungkinkan interaksi yang lebih efektif tidak hanya untuk alasan pribadi, tetapi juga untuk tujuan yang lain sehingga humas dapat memanfaatkan kesempatan tersebut untuk melakukan fungsi manajemen kehumasan, yaitu berinterkasi dengan lingkungan eksternal secara dua arah. Sehingga, pemerintah dapat berkomunikasi dengan masyarakat yang aktual dan potensial secara lebih efisien.

Graham (2014) menyatakan bahwa penggunaan media sosial oleh pemerintahan lokal merupakan pilihan penting, karena pemerintahan menyadari pentingnya media sosial sebagai sarana memberikan informasi dan membangun hubungan dengan warga. Misalnya saja, Facebook dan Twitter adalah alat media sosial yang paling banyak digunakan dan merupakan media untuk mempromosikan program dan kegiatan. Sheldon et al (2015) mengatakan bahwa Instagram 
menawarkan kesempatan untuk terlibat langsung dengan kelompok masyarakat. Instagram tampaknya diarahkan kepada khalayak yang lebih berorentasi teknis. Ada hal positif dalam interaksi interpersonal dan menggunakan Instagram untuk kesejukan, tujuan kreatif, dan pengawasan.

Media sosial juga mendorong adanya dialog melalui penggunaan media sosial, pemerintah daerah memungkinkan demokrasi melalui cara-cara yang terbuka, transparan, dan interaktif dengan memanfaatkan media baru ini. Warga diberi saluran lain untuk belajar dan berpartisipasi dalam kegiatan pemerintah. Selain itu, pemerintah daerah mengambil keuntungan dari fitur interaksi media sosial dan memungkinkan untuk berdialog dengan warga tentang informasi, pertanyaan, dan ide yang berkaitan dengan pemerintah daerah mereka. (Gruzd et al, 2018).

Guidry et al (2017), meskipun media sosial telah digunakan oleh para praktisi hubungan masyarakat sebagai kendaraan utama untuk komunikasi krisis, sedikit yang diketahui tentang bagaimana platform ini digunakan oleh organisasi kesehatan masyarakat dalam situasi wabah penyakit menular dan bagaimana ini mungkin telah membentuk tanggapan publik terhadap wabah pada dan dari media sosial. Sebagai contoh ketika ada wabah Ebola oleh tiga organisasi kesehatan utama, Pusat Pengendalian dan Pencegahan Penyakit (CDC), Organisasi Kesehatan Dunia (WHO), Médecins Sans Frontières (MSF, juga dikenal sebagai Doctors without Borders, di Twitter dan Instagram, berfokus pada jenis komunikasi yang digunakan selama wabah, konten dan konteks komunikasi ini, dan tanggapan yang mereka dapat dari publik. Sementara kedua platform digunakan oleh ketiga organisasi kesehatan, hasilnya menunjukkan bahwa Instagram mungkin merupakan platform yang sangat berguna untuk membangun komunikasi interaktif yang bermakna dengan masyarakat pada saat krisis kesehatan global, sebagaimana dibuktikan oleh tingkat keterlibatan yang jauh lebih besar di pihak organisasi kesehatan dan masyarakat. Selain itu, temuan kami menunjukkan bahwa pesan media sosial mungkin paling efektif ketika digunakan oleh organisasi kesehatan yang akrab dengan dan untuk publik, dan ketika didasarkan pada penggunaan strategis prinsipprinsip komunikasi risiko seperti perpesanan berbasis solusi, penggabungan citra visual, dan pengakuan akan ketakutan dan kekhawatiran publik.

Sama halnya dengan pandemi Covid-19 yang masih berlangsung, Limaye et al (2020) menyatakan dengan adanya pandemi Covid-19, maka konsekuensinya harus menjaga jarak fisik, sehingga orang sangat bergantung pada menjaga konektivitas dengan menggunakan jaringan sosial digital global, untuk memfasilitasi interaksi manusia dan berbagi informasi. Pengguna media sosial semakin melihat individu tepercaya dalam jaringan rekan mereka yang mendukung produksi dan pertukaran informasi berharga dan sebagai sumber informasi yang otoritatif. Metode berbagi dan memvalidasi informasi ini kontras dengan metode yang lebih langsung dikendalikan oleh perantara (misalnya, media tradisional), yang memiliki pengetahuan khusus dan tanggung jawab khusus terkait dengan verifikasi dan berbagi informasi. Dalam pandemi Covid-19, tidak mengherankan jika warga beralih ke realitas digital yang baru untuk mendapatkan informasi dan arahan. 


\section{HASIL DAN PEMBAHASAN}

\section{A. Instagram sebagai Media Sosialisasi}

Sejak munculnya kasus Covid-19 di Indonesia, Bupati Banyumas Achmad Husein mulai melakukan sosialiasi kepada msyarakat melalui akun media sosial Instagram@ir_achmadhusein. Media sosial Instagram Bupati tersebut tidak digunakan untuk kepentingan pribadi. Bupati Banyumas menggunakan akun Instagram untuk memberikan sosialiasi kepada masyarakat luas. Pada masa pandemi, secara berkala memberikan informasi mengenai data-data kasus Covid19 dan dilengkapi dengan imbauan dan regulasi yang terkait dengan penanganan Covid-19.

Bupati Banyumas Achmd Husein untuk pertama kalinya mengunggah soal Covid-19 pada 3 Maret, pada saat pertama kalinya pemerintah pusat mengumumkan secara resmi ada dua WNI yang positif Covid-19. Sejak saat ini, akun tersebut secara berkala terus memmberikan informasi mengenai Covid-19.

Sebagai media informasi yang berbentuk teks dan grafis, akun Instagram @ir_achmadhusein tidak saja memberikan gambaran mengenai perkembangan kasus Covid-19 di Banyumas mulai dari orang dalam pemantauan (ODP), pasien dalam pengawasan (PDP) maupun positif Covid-19. Informasi melalui grafis tersebut terus diperbarui jika ada perkembangan baru seperti pasien positif baru, pasien yang telah sembuh, warga yang masuk ODP, penduduk yang termasuk PDP sampai pasien yang meninggal dunia. Dalam grafis, tidak dilengkapi dengan nama pasien, melainkan asal pasien.

Meskipun bentuknya sosialiasi, namun Instagram @ir_achmadhusein memilih untuk membuka kolom komentar, sehingga masyarakat dapat mempertanyakan apa yang disampaikan. Warga sering memberikan pertanyaan melalui media tersebut, meski tidak banyak yang mendapat jawaban secara keseluruhan.

Dalam akun tersebut, Bupati juga memberikan informasi lainnya terkait dengan bantuan sosial (bansos). Bupati memberikan informasi mengenai bansos kepada masyarakat penerima yang merupakan keluarga terkena dampak Covid-19. Dengan informasi tersebut, maka masyarakat dapat memberikan respons terhadap bansos yang disalurkan.

Selain itu, akun Instagram Bupati Banyumas juga mengimbau kepada warga yang ada di perantauan, untuk tidak mudik pada saat menjelang Lebaran. Dalam imbauan yang dilakukan, ada unggahan mengenai foto Bupati Banyumas Achmad Husein yang kalimat "Sayangi keluarga dengan cara tidak mudik, selama masih ada wabah Covid-19."

Bupati Banyumas memilih Instagram menjadi salah satu media sosial merupakan hal strategis. Sebab, menurut Pertiwi et al (2019), dengan penggunaan media sosial, pemerintah dapat memerankan fungsinya dalam mencapai "good governance" dengan memperhatikan empat elemen yakni akuntabilitas, partisipatif, supremasi hukum, dan transparan. Dalam hal ini, pemerintah harus mempertimbangkan penerapan konsep "good governance" untuk mencapai implementasi pemerintahan negara yang solid, bertanggung jawab serta efisien dan 
efektif. Dalam konteks akun Instagram @ir_achmadhusein, Bupati telah memberikan informasi secara transparan mengenai data jumlah kasus Covid-19, kemudian informasi mengenai bansos untuk masyarakat secara transparan dan akuntabel, serta memberikan kesempatan bagi msyarakat untuk ikut berpartisipasi dalam usulan maupun sanggahan.

\section{B. Instagram sebagai Sarana Informasi dan Edukasi Covid-19}

Akun Bupati Banyumas@ir_achmadhusein tidak hanya menampilkan infografis atau pesan teks, melainkan juga berisi video. Sejak Maret hingga Juni, unggahan video paling dominan jika dibandingkan dengan akun unggahan lainnya seperti infografis dan teks. Sejak awal Maret hingga akhir Juni, video pernyataan Bupati Banyumas yang diunggah di akun @ir_achmadhusein berisi berbagai informasi, edukasi, imbauan dan ajakan kepada masyarakat di Banyumas.

Salah satu contoh "postingan" yang mendapat respons cukup banyak adalah unggahan 1 April 2020, karena ada kasus cukup menonjol yaitu penolakan jenazah positif Covid-19. Dalam unggahan tersebut, bupati meminta maaf kepada masyarakat Banyumas terkait penolakan tersebut. Bupati memberikan edukasi kepada masyarakat bahwa virus yang ada dalam jenazah positif Covid-19 akan ikut mati setelah 7-9 jam, sehingga tidak perlu ditakutkan. Bupati juga menceritakan bahwa dirinya menggali dan ikut mengubur jenazah Covid-19 sebagai upaya untuk mengedukasi warga agar tidak ketakutam ketika ada pasien yang meninggal.

Unggahan lainnya yang mirip dengan itu adalah "postingan" video Bupati Banyumas Achmad Husein ketika menjadi bintang tamu acara Trans7 dengan pembaca acara Deddy Corbuzier. Video yang diunggah di akun@ir_achmadhusein pada 14 April itu berisi mengenai wawancara mengenai penolakan jenazah Covid19. Dalam kesempatan itu, bupati menerangkan bahwa setelah dirinya ikut serta membawa peti dan mengubur jenazah positif Covid-19 dan tidak ada masalah dengan kesehatannya, maka warga semakin teredukasi, sehingga banyak kemudian desa yang mau menerima jenazah positif Covid-19. Dalam video wawancara itu, bupati juga menyatakan bahwa edukasi tersebut tidak lepas dari sosialisasi yang dilakukan ulama dan tokoh agama serta para dokter dan petugas kesehatan lainnya.

Video-video lainnya yang diunggah oleh bupati di akun Instagramnya berisi berbagai tema, terutama soal perkembangan kasus Covid-19 baik asal daerah dan riwayat perjalanannya, kemudian sosialisasi mengenai cara-cara pencegahan dan disiplin dalam protokol kesehatan penanggulangan Covid-19, serta informasi mengenai bansos baik dari pemerintah pusat, provinsi, maupun kabupaten.

Instagram, menurut Margaretha dan Sunarya (2017), memiliki potensi untuk digunakan sebagai media sosialisasi karena mempunyai fitur-fitur yng memenuhi tujuh aspek yaitu credibility (kredibilitas), contex (konteks), content (konten), clarity (kejelasan), continuity and sonsistency (kontinuits dan konsistensi), channels (saluran), dan capability of the audience (kapabilitas khalayak). Instagram memiliki cirikhas yang mengedepankan pesan visual dan interaktivitas yang tinggi. Dan sosialisasi dengan Instagram merupakan salah satu media sosial populer yang digunakan oleh instansi baik pemerintah maupun swasta. 
Dalam menggunakan media sosial sebagai sarana informasi dan edukasi, menurut Luttrel (2015), pemerintaj perlu memiliki strategi dan taktik. Jika diterapkan secara benar dan dikelola dengan baik, perencanaan sosial media dapat menjadi sebuah penggerak yang dapat digunakan untuk suatu hal yang baru. Selain itu, khalayak dapat berpartisipasi dalam diskusi. Ada empat tahap dalam mengelola media sosial yaitu share (membagikan), optimize (mengoptimalisasi), manage (mengelola) dan engage (mengikutsertakan). Dalam konteks Instagram Bupati Banyumas, media sosial tersebut telah melalui empat tahap tersebut, sehingga dapat dimanfaatkan secara optimal khususnya dalam memberikan informasi dan melaksanakan edukasi.

\section{Instagram sebagai Media Interaksi}

Bupati Banyumas Achmad Husein memanfaatkan secara optimal fitur-fitur yang ada dalam media sosial Instagram, contohnya adalah ftur "Live Instagram". Fitur ini memfasilitasi peggunanya untuk melakukan siaran langsung dan berinteraksi dengan para pengikutnya, meski pengikut hanya dapat memberikan pertanyaan dan pernyataan secara teks. Dalam setiap kesempatan "Live Instagram", Bupati menyediakan waktu menjawab pertanyaan-pertanyaan yang disampaikan oleh para "followers"-nya. Berbagai macam pertanyaan disampaikan, tetapi umumnya terkait dengan Covid-19. Sebagai contoh, banyak pengguna yang meminta informasi soal tes "swab", perkembangan di daerah tertentu, bansos akibat dampak Covid-19, bahkan sampai hal-hal yang sepele.

Bupati memanfaatkan fitur tersebut untuk berinteraksi secara dekat dengan masyarakat di ruang virtual media sosial Instagram, sehingga kadang ada hal-hal yang lucu yang terlontar hingga dapat menjadi viral. Misalnya, ketika ada pengikut yang memberikan pernyataan bahwa Bupati seperti "bakul peso" atau penjual pisau, sehingga membuat kelucuan di ruang virtual tersebut. Bahkan, kemudian Bupati secara sukarela merespons dengan tertawa sambil menggeser peci hitam yang dikenakannya sambil menyatakan,"Aku geget". Respons tersebut menunjukkan bahwa antara pemimpin dengan masyarakatnya cukup dekat, sehingga mampu menciptakan guyonan meski dalam ruang virtual.

Menurut Furqon (2018), respons dalam Instagram akan lebih menarik jika menggunakan unsur audio maupun visual. Beberapa fenomena menarik yang muncul adalah unggahan yang berupa gambar dan video dalam media sosial mendapatkan respons positif jika dibandingkan dengan unggahan teks, karena memang audio visual lebih interaktif. Pada saat sekarang, khalayak cenderung lebih memilih informasi melalui video apabila dibandingkan dengan gambar atau teks. Dalam konteks "Live Instagram" Bupati Banyumas biasanya akan diikuti oleh ribuan pengikut yang ikut serta melakukan respons di kolom komentar. Di sinilah muncul interaksi antara pemimpin dengan masyarakatnya dalam kondisi serius tetapi santai bahkan kadang ada lelucon yang muncul dalam interaksi tersebut.

Interaksi sosial melalui media sosial tersebut, menurut Hao et al (2016), karena didukung oleh khalayak yang telah menggunakan media sosial, bahkan peningkatannya cukup signifikan. Seperti halnya Instagram Bupati Banyumas yang 
cukup menyita perhatian khalayak salah satunya adalah "live Instagram" tersebut. Sebab, khalayak dapat mengajukan pertanyaan secara interaktif.

\section{KESIMPULAN}

Sebagai seorang pemimpin daerah, Bupati Achmad Husein memanfaatkan mesia sosial Instagram melalui akun@ir_achmadhusein dengan memanfaatkan berbagai macam fitur dalam berkomunikasi dengan masyarakat. Ada tiga jenis bentuk komunikasi yang dilakukan yakni melalui unggahan teks dan grafis, "postingan" video informatif dan "live Instagram". Pada umumnya, selama Maret hingga Juni, informasi mengenai Covid-19 merupakan isu paling dominan. Isi pesan yang disampaikan melalui ketiga fitur yang digunakan oleh Bupati Banyumas ada kemiripan yaitu informasi perkembangan kasus Covid-19, sosialiasi mengenai Covid-19, imbauan kepada masyarakat terkait dengan pandemi Covid-19, informasi mengenai bantuan sosial kepada masyarakat, dan berbagai hal terkait dengan pandemi Covid-19 di Banyumas.

\section{DAFTAR PUSTAKA}

Anggreani, MD dkk. 2020. Ruang Publik Virtual Sebagai Pintu Komunikaso Government to Citizen (Studi Kasus: Perbandingan Media Sosial Pemerintah Kota Yogyakarta dan Surabaya). Jurnal MODERAT,Volume 6, Nomor 1, Februari 2020, ISSN: 2442-3777 (cetak) Website: https://jurnal.unigal.ac.id/index.php/moderat ISSN: 2622-691X (online)

Cangara, Hafied. 2018. Pengantar Ilmu Komunikasi. Depok. PT Raja Grafindo Persada.

Duraisamy, B., Sengottaiyan, K., Rathimaswamy, J. 2020. Social Media Reigned by Information or Misinformation About COVID-19: A Phenomenological Study. SSRN Electronic Journal 09 (03):585-602-April 2020.

Furqon, MA dkk. 2018. Analisis Sosial Media Pemerintah Daerah di Indonesia Berdasarkan Respon Warganet. Jurnal Sosioteknologi volume 17. No 2 tahun 2018

Guidry, et al. 2017. Ebola on Instagram and Twitter: How health organizations address the health crisis in their social media engagement. Public Relations Review. Volume 31, Issue 3, September 2017, Pages 477-486.

Hao $\mathrm{X}$ et al, 2016. How to strengthen the sosial media interactivity of EGovernment: Evidence from China. Online Information Review. Volume 40. Issue 1. 8 February 2016. ISSN: 1468-4527 
Hine, C. 2000. Virtual Ethnography. London. SAGE Pubblications

Https://wearesocial.com/digital-2020

Limaye. Et al. 2020. Building trust while influencing online COVID-19 content in the social media world. https://www.thelancet.com/journals/landig/article/PIIS2589$\underline{7500(20) 30084-4 / \text { fulltext }}$

Luttrel, R. 2015. Social Media How To Engage,Share and Connect. Maryland. The Rowman \& Littlefield Publishing Group, Inc.

Margaretha, L dan Sunarya, DM. 2017. Instagram Sebagai Media Sosialisasi 9 Program Unggulan Pemerintah (Studi Kasus pada Bagian Hubungan Masyarakat Kementrian Koperasi dan Usaha Kecil dan Menengah Republik Indonesia pada Instagram

Prajarto, N. 2018. Netizen dan Infotainment: Studi Etnografi Virtual pada Akun Instagram@lambe_turah. Jurnal Ilmu Komunikasi, Prodi Ilmu Komunikasi, FISIP, Universitas Atma Jaya Yogyakarta. Volume 15, No. 1, Juni 2018: 3346

Perez, S. 2020. Report: WhatsApp has seen a 40\% increase in usage due to COVID19 pandemic. https://techcrunch.com/2020/03/26/report-whatsapp-has-seena-40-increase-in-usage-due-to-covid-19-pandemic/

Pertiwi, et al. 2019. Smart City through Social Media: In Creating Good Governance in the Government of West Java. International Journal of Multicultural and Multireligious Understanding (IJMMU) Jakarta International Conference on Social Sciences and Humanities (JICoSSH) Vol. 6, Special Issue 4, February 2019.

Susanto, EH. 2017. Media Sosial Sebagai Pendukung Jaringan Komunikasi Politik. Jurnal ASPIKOM, Volume 3 Nomor 3, Juli 2017, hlm 379-398

Taprial, V \& Kanwar, P. 2012. Understanding Social Media. Ventus Publishing. ISBN (978-87-7681-992-7).

West, et al. 2010. Introducing Communication Theory. New York. The McGrawHill Companies, Inc. 